\title{
Effects of the glyphosate-resistance gene and of herbicides applied to the soybean crop on soil microbial biomass and enzymes
}

\author{
André Shigueyoshi Nakatani ${ }^{\mathrm{a}, \mathrm{b}, 1}$, Marcelo Ferreira Fernandes ${ }^{\mathrm{c}, 1}$, \\ Rosinei Aparecida de Souza ${ }^{\mathrm{a}, 2}$, Adriana Pereira da Silva ${ }^{\mathrm{a}, \mathrm{b}}$, \\ Fábio Bueno dos Reis-Junior ${ }^{\mathrm{d}}$, Iêda Carvalho Mendes ${ }^{\mathrm{d}}$, Mariangela Hungria ${ }^{\mathrm{a}, *}$ \\ a Embrapa Soja, C.P. 231, 86001-970 Londrina, PR, Brazil \\ ${ }^{\mathrm{b}}$ Postdoctoral Research Fellow from CAPES/Fundação Araucária, Brasília/Curitiba, DF/PR, Brazil \\ ${ }^{\mathrm{c}}$ Embrapa Tabuleiros Costeiros, C.P. 44, 49025-040 Aracaju, SE, Brazil \\ d Embrapa Cerrados, C.P. 08223, 73301-970 Planaltina, DF, Brazil
}

\section{A R T I C L E I N F O}

\section{Article history:}

Received 29 July 2013

Received in revised form 5 March 2014

Accepted 19 March 2014

\section{Keywords:}

Glycine max

Soil-enzyme activities

Soil-microbial biomass

Soil quality, Transgenic soybean

\begin{abstract}
A B S T R A C T
Glyphosate, a broad-spectrum herbicide used for the non-selective control of weeds, inhibits 5enolpyruvylshikimate-3-phosphate synthase, a key enzyme in the synthesis of aromatic amino acids in the shikimic acid pathway in plants, fungi and bacteria, thus impairing the synthesis of proteins required for various life processes. Soybean genetically engineered to be glyphosate resistant (GR or Roundup Ready, RR) represents the most cultivated transgenic crop globally, including Brazil. There are concerns about the effects of RR transgenic soybean and of glyphosate on soil microbial communities and their functioning. Our study was designed to detect changes in soil microbial biomass-carbon (MBC) and -nitrogen (MB-N) and in enzyme activities [beta-glucosidase (GLU) and acid phosphatase (PHO)] in a large set of field trials performed at six sites in Brazil for two cropping seasons. We evaluated the effects of the RR transgene, glyphosate and weed management (RR soybean + glyphosate vs. conventional soybean + conventional herbicides), with three pairs of nearly isogenic soybean cultivars evaluated per site. Soils were sampled from the $0-10 \mathrm{~cm}$ layer, between cropped lines, during the cropping seasons $2004 / 2005$ and 2005/2006, at the R2 stage of soybean growth. Univariate and contrast analyses were performed in addition to multivariate analyses including all four microbial variables, and denominated as soil microbial variables (SMV). In general, microbial parameters and SMV were not affected by the transgene, type of herbicide or weed management. Differences were, rather, related to site, cropping season and cultivar.
\end{abstract}

() 2014 Elsevier B.V. All rights reserved.

\section{Introduction}

Glyphosate-resistant (GR or Roundup Ready ${ }^{\circledR}, \mathrm{RR}$ ) soybean [Glycine max (L.) Merr.] represents the most-cultivated transgenic crop. In Brazil, cultivation of RR genotypes continues to increase, mainly due to broad adoption of glyphosate for weed control (Pereira et al., 2008; Zobiole et al., 2010a,b,c); in the 2010/2011

\footnotetext{
* Corresponding author. Tel.: +55 43 33716206; fax: +55 4333716100 .

E-mail addresses: andrenakatani@yahoo.com.br (A.S. Nakatani), marcelo.fernandes@embrapa.br (M.F.Fernandes),rosyquimica@yahoo.com.br (R.A. de Souza),drikapera@yahoo.com.br (A.P. da Silva), fabio.reis@embrapa.br (F.B. dos Reis-Junior), mariangela.hungria@embrapa.br, hungria@pq.cnpq.br, biotecnologia.solo@hotmail.com (M. Hungria).

1 Both authors contributed equally to the study.

2 Current address: IAPAR, C.P. 481, 86001-970 Londrina, PR, Brazil.
}

growing season, RR genotypes occupied $86 \%$ of the area cultivated to soybean globally (ISAAA, 2012). In response to the widespread use of RR soybean, the quantity and frequency of glyphosate applications have escalated worldwide in recent years (Gomez et al., 2009), raising concerns regarding potential environmental impacts (Weaver et al., 2007).

Glyphosate [N-(phosphomethyl) glycine; Roundup ${ }^{\circledR}$, Monsanto, St. Louis, MO] is a broad-spectrum herbicide used for the non-selective control of weeds. It inhibits 5-enolpyruvylshikimate3-phosphate synthase, a key enzyme in the synthesis of aromatic amino acids in the shikimic acid pathway in plants, fungi and bacteria (Gomez et al., 2009). Without these amino acids, organisms are unable to synthesize certain proteins essential for metabolism (Ware, 2000). Transgenic soybean produces a glyphosate-insensitive 5-enolpyruvylshikimate-3-phosphate synthase (EPSPS) (Reddy et al., 2001). 
Glyphosate is often described as a simple molecule, easily degraded, exhibiting little or no activity in soil due to its rapid adsorption on inorganic and organic particles, with a half-life ranging from days to months (Forlani et al., 1999; Jonge and Jonge, 1999; Duke and Powles, 2008). Many soil microorganisms can metabolize pesticides and use xenobiotics as sources of carbon, energy and nutrients (Durkin, 2003). The rate at which glyphosate is mineralized is related to biomass and activity of microorganisms, determining its persistence in the soil (Wiren-Lehr et al., 1997).

Even though the herbicide is not applied directly to the soil, a significant amount may reach its surface during broadcast preplanting or early-season applications, with harmful effects on soil microorganisms. The quantity of herbicide available to the soil microorganisms depends on factors such as soil nutrient and $\mathrm{pH}$ status, temperature, and moisture content (Weber et al., 1993).

Glyphosate consumption is increasing globally, due both to the expanded area planted to RR crops, and to higher amounts applied per unit area. The increased application of glyphosate has raised concerns about changes in soil-microbial communities, demanding monitoring of microbial populations and activities (Kremer et al., 2005; Johal and Huber, 2009). Microbial biomass is correlated with essential functions in the soil, such as the decomposition of organic matter, cycling of mineral nutrients, plant-growth promotion, biological control of diseases and insects and degradation of xenobiotics. It has been proposed as a sensitive parameter to measure disturbances caused to the soil environment, particularly in relation to those resulting from agricultural management (e.g. Sylvia et al., 2005; Nogueira et al., 2006; Kaschuk et al., 2010, 2011; Lopes et al., 2013), including the monitoring of effects related to transgenic crops (Souza et al., 2008a,b, 2013). Similarly, microbial enzymatic activities are considered to be responsive to changes in the environment caused by natural or human-induced factors (Puglisi et al., 2006; Kaschuk et al., 2010; Mendes et al., 2012). The $\beta$-glucosidase enzyme plays a critical role in soils, releasing low molecular weight sugars that represent important energy sources for soil microorganisms (Bandick and Dick, 1999). The acid phosphatase (predominant in acidic soils) can provide useful information on soil biochemical activity in the tropical Brazilian soils characterized by low pH values (Balota et al., 2013). Urease is also an important enzyme; however, the experimental areas of our study have not received $\mathrm{N}$-fertilizers and the soils are very poor on $\mathrm{N}$ and thus the activity of this enzyme was not evaluated.

Contrasting results have been observed by various researchers evaluating the impact of glyphosate on soil microbiota. Studies by Haney et al. $(2000,2002)$ indicated that glyphosate application can increase soil-microbial biomass, respiration and $\mathrm{C}$ and $\mathrm{N}$ mineralization. Evaluations on Brazilian soils indicated that glyphosate was rapidly metabolized to aminophosphonic acid, and increased respiration and fluorescein diacetate (FDA) hydrolytic activity were observed (Araujo et al., 2003). Investigation conducted under controlled conditions in the Midwestern USA found limited or no effect of glyphosate or of cropping RR soybean on soil-microbial biomass (Liphadzi et al., 2005). Similar results were observed in Brazil by Zilli et al. (2008), who found that no significant changes occurred in microbial-biomass content, soil basal respiration or metabolic quotient $\left(q \mathrm{CO}_{2}\right)$. Pereira et al. (2008), in a field experiment, also observed that glyphosate application had no impact on soil $\mathrm{CO}_{2}$ production or on microbial biomass. The study of Gomez et al. (2009) showed that glyphosate application promoted an initial inhibitory effect that affected microbial biomass, microbial respiration rate, $q \mathrm{CO}_{2}$ and dehydrogenase activity; however, the effect was transitory. In contrast, Bohm et al. (2007) showed that the application of glyphosate resulted in lower $\mathrm{C}$ incorporation by microbial biomass, as well as increased respiration.

One concern regarding the use of transgenic plants and their effects on soil microorganisms is the so-called "unexpected effect".
Donegan et al. (1995) suggested that unexpected changes in plant traits resulting from genetic modification may impact soil microbial communities. Novel proteins have been shown to be released from transgenic plants into the soil ecosystem, and their presence can influence microbial communities by selectively stimulating the growth of specific organisms able to use these molecules (Dunfield and Germida, 2004). However, as pointed out by Dunfield and Germida (2004), genetically engineered plants differ by only one or two genes, begging the question of whether the difference is enough to influence rhizospheric microorganisms.

The great majority of the studies assessing the effects of transgenic plants and specific herbicides application is limited to greenhouse conditions, using only the transgenic treatments without comparison against the parental non-transgenic plants. When the studies are carried out under field condition, few sites are evaluated and in general for only one cropping season. The present work is part of a large set of experiments performed in six field sites of Brazil, covering several edaphoclimatic conditions, for two cropping seasons, aiming to investigate the effects of transgene resistance to glyphosate, of herbicides and of weed management strategies on soybean crop. The RR gene was introduced in the parental genotypes, in an agreement between Embrapa and Monsanto ${ }^{\circledR}$; therefore, the comparison between transgenic and nearly isogenic parental genotypes was possible, what is rare in studies with transgenic soybean, once the material usually belongs to the private sector. The results from our study were designed to detect changes in soil microbial biomass and enzyme activities, evaluated both individually and pooled as a multivariate response.

\section{Materials and methods}

\subsection{Geographic location, general description of the field sites, treatments and experiment logistics}

The experiments were set up during the cropping seasons of $2003 / 2004,2004 / 2005$ and 2005/2006, under no-tillage management, at six sites in Brazil (States between parentheses): Passo Fundo (Rio Grande do Sul); Ponta Grossa (Paraná) (except in 2003/2004); Londrina (Paraná); Uberaba (Minas Gerais); Planaltina (Federal District); and Luiz Eduardo Magalhães (Bahia). Details about the location, climate and soil classification at each site were given elsewhere (Hungria et al., 2014), and the locations of the sites are shown in Fig. 1. Soil chemical and physical properties were described before (Hungria et al., 2014), but are also supplied in Supplementary Table S1. Evaluation of microbial parameters started from the second year after the establishment of the field experiments.

Supplementary Table S1 related to this article can be found, in the online version, at http://dx.doi.org/10.1016/j.fcr.2014.03.010.

Each trial was conducted in a completely randomized block design, with 5 treatments $\times 3$ cultivars, with 6 replicates, in a total of 90 plots. The five treatments consisted of: (T1) RR soybean+glyphosate $\left(2 \mathrm{Lha}^{-1}\right)$ [Roundup Transorb ${ }^{\circledR}$, Monsanto, applied 20-30 days after emergence]; (T2) RR soybean + conventional herbicides $\left[0.5 \mathrm{~L} \mathrm{ha}^{-1}\right.$ of Select 240 (Clethodim, Milenia), mixed with Assist mineral oil at $0.5 \%$ of the volume (narrow-leaf weeds), and Classic (Chlorimurum-ethyl, DuPont) at $80 \mathrm{~g} \mathrm{ha}^{-1}$ (broad-leaf weeds)]; (T3) conventional soybean + conventional herbicides; (T4) RR soybean + hand-weed control; (T5) conventional soybean + hand-weed control.

Three pairs of cultivars, each of which included a parental soybean genotype and its respective nearly isogenic RR genotype, were cropped at each site. Soybean cultivars tested in Ponta Grossa and Londrina were Conquista/ValiosaRR (Cultivar 1=C1); BRS133/BRS245RR (Cultivar 2=C2); and Embrapa 59/BRS244RR 


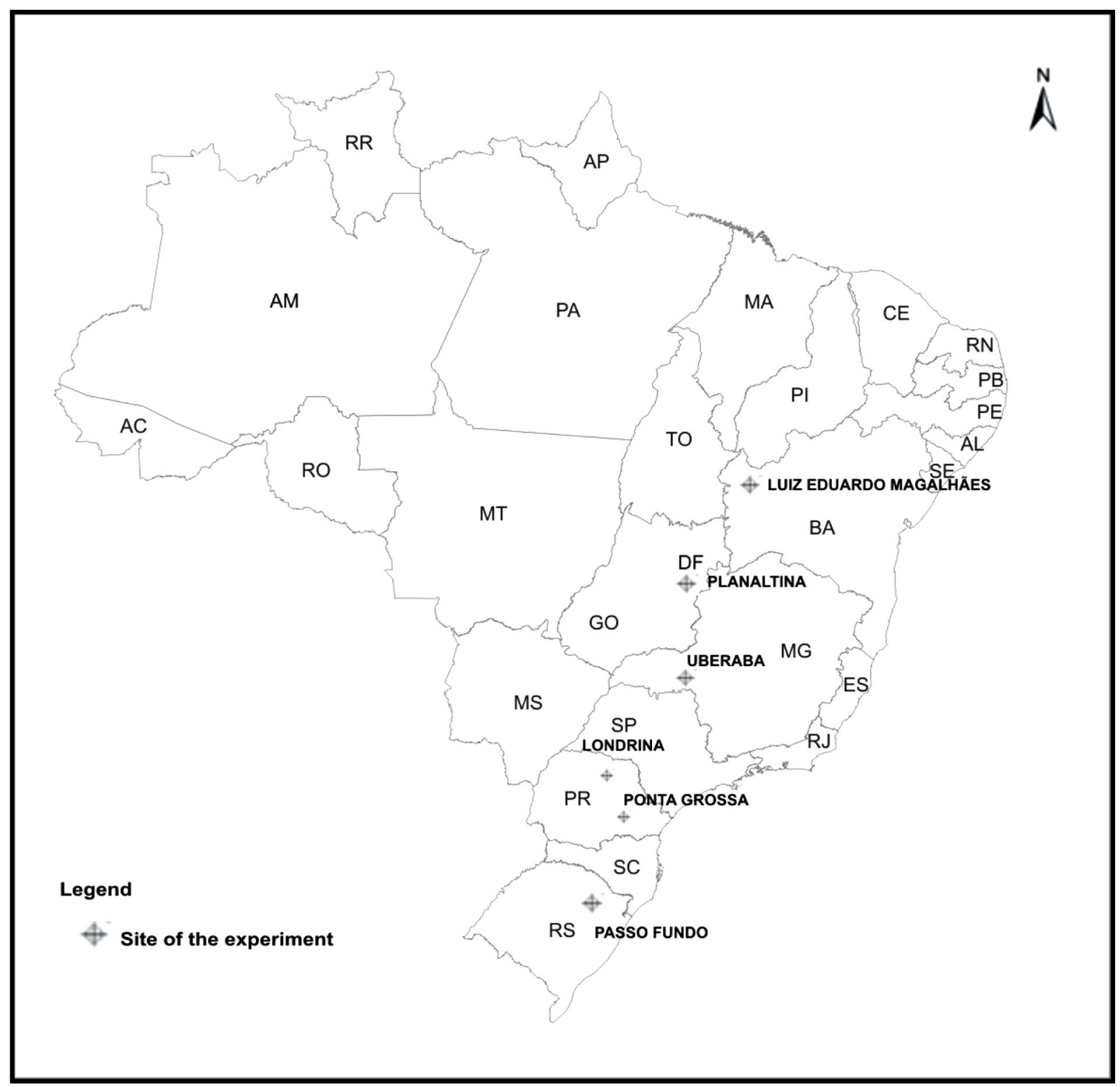

Fig. 1. Map indicating the nine sites where the field experiments were performed.

(Cultivar 3=C3). These same cultivars were tested in Passo Fundo, except in 2004/2005 and 2005/2006, when Conquista/ValiosaRR were replaced by Embrapa58/BRS242RR. In 2003/2004, the cultivars tested in the Central region areas (Uberaba, Planaltina, Luiz Eduardo Magalhães) were Conquista/ValiosaRR (Cultivar 1 =C1); BRS133/BRS245RR (Cultivar 2=C2); and Jataí/SilvâniaRR (Cultivar $3=$ C3). In 2004/2005 and 2005/2006, the same cultivars were tested, except for BRS133/BRS245RR, which were replaced by Celeste/BalizaRR. Genealogy and maturity groups of parental conventional types were as follows: Conquista MG/BR 46 (Lo76-4484 × Numbaíra, G.8.1); BRS 133 (FT Abyara $\times$ BR 83146, G.7.3); Embrapa 59 (FT Abyara $\times$ BR83-147, G.7.3); Embrapa 58 (Paraná $\times$ BR83-143, G.7.4); BRS/GO Jataí [Embrapa 313 (Anhanguera) $\times$ BR92-31910 (Cristalina CARDF-30*3 $\times$ FT Estrela), G.8.9]; BRS Celeste (Bossier $\times$ BR 1 T, G.8.1); they all have determinate type of growth. Replacements were made when the cultivars used failed to show good performance, being replaced by betteradapted, newly released cultivars.

All areas were managed under no-tillage system and cropped to soybean in the summer. In the winter, the areas were sown with black oat (Avena strigosa L.) or wheat (Triticum aestivum L.) in the South Region (Passo Fundo, Ponta Grossa and Londrina), and pearlmillet (Pennisetum americanum) in the Central Region (Uberaba, Planaltina and Luiz Eduardo Magalhães).

The soybean seeds were inoculated with a peat-based inoculant produced at Embrapa Soja and containing a 1:1 mixture of $B$. elkanii strain SEMIA 587 and B. diazoefficiens strain CPAC 7 (=SEMIA 5080) ( $10^{9}$ cells $\mathrm{g}^{-1}$ of peat). Inoculation involved application of a slurry prepared with $200 \mathrm{~g}$ of inoculant in $300 \mathrm{~mL}$ of a $10 \%$ sucrose sticker solution per $50 \mathrm{~kg}$ of seeds, and the inoculant was applied to result in a concentration of 1.2 million cells seed ${ }^{-1}$. Sowing was done manually, with 25-30 viable seeds per meter of row. The experimental plots were $5.0 \mathrm{~m} \times 6.0 \mathrm{~m}$ in size, and spaced by $1.0 \mathrm{~m}$. Each plot consisted of 10 rows, sown $50 \mathrm{~cm}$ apart.

\subsection{Sampling and laboratory analyses}

For evaluation of microbial parameters, soil samples were collected from the top layer $(0-10 \mathrm{~cm})$ between cropped lines. Microbial biomass-carbon $(\mathrm{MB}-\mathrm{C})$ and -nitrogen $(\mathrm{MB}-\mathrm{N})$ were 
analyzed in 2004/2005 and 2005/2006 for cultivars C1, C2 and C3, whereas beta-glucosidase (GLU) and acid phosphatase (PHO) data were obtained only in season 2005/2006 for cultivar C1. At the R2 stage of soybean growth (Fehr et al., 1971) ten soil samples from 0to $10-\mathrm{cm}$ depth between the cropped lines were randomly taken in each plot (replicate) and mixed to obtain a composite sample. At the laboratory, samples were homogenized and sieved ( $4 \mathrm{~mm}, 5 \mathrm{mesh}$ ), and their moisture content determined by drying a 10 -g subsample for $12 \mathrm{~h}$ at $105^{\circ} \mathrm{C}$. On the following day, the moisture content of the samples was adjusted to $40 \%$ (dry basis) of the water-holding capacity (WHC) (Vance et al., 1987) by adding distilled water.

MB-C and MB-N were determined by the fumigation-extraction method of Vance et al. (1987), slightly modified as described before (Hungria et al., 2009). Eight subsamples ( $20 \mathrm{~g}$ ) of each composite soil sample were weighted and stored in glass jars $(300 \mathrm{~mL})$, four of which were submitted to fumigation, and the other four were left non-fumigated. Fumigated and non-fumigated samples were incubated in the dark at $25 \pm 2{ }^{\circ} \mathrm{C}$ for $16 \mathrm{~h}$. After the incubation, the $C$ was extracted from the samples by adding $50 \mathrm{~mL}$ of extractor solution $\left(0.5 \mathrm{~mol} \mathrm{~L}^{-1} \mathrm{~K}_{2} \mathrm{SO}_{4}\right)$, shaking $(175 \mathrm{rpm}, 1 \mathrm{~h})$, centrifuging (3000 rpm, $10 \mathrm{~min}$ ) and filtering as described by Franchini et al. (2007). The $C$ contents of the extracts were determined by oxidation with $\mathrm{Mn}^{3+}$ and evaluation on a spectrophotometer (Bartlett and Ross, 1988).

The $\mathrm{N}$ contents of the extracts were determined by adding to the extract $1.5 \mathrm{~mL}$ of concentrated $\mathrm{H}_{2} \mathrm{SO}_{4}$ and $50 \mathrm{mg}$ of catalyst $\left(\mathrm{K}_{2} \mathrm{SO}_{4}+\mathrm{CuSO}_{4}, 10: 1\right)$; after digestion, the product was diluted with distilled water and $\mathrm{N}$ quantified by the spectrophotometric determination of $\mathrm{NH}_{4}$ using the indophenol-blue method (Feije and Anger, 1972).

MB-C and MB-N values were estimated from the differences between the fumigated and non-fumigated samples, employing a $K_{\mathrm{CE}}$ value of 0.38 and a $K_{\mathrm{NE}}$ value of 0.54 (Brookes et al., 1985).

Beta-glucosidase (GLU) and acid phosphatase (PHO) activities were determined according to Tabatabai (1996), based on the hydrolysis of $p$-nitrophenyl $\beta$-glucoside and $p$-nitrophenyl phosphate substrates and the colorimetric determination of the resulting $p$-nitrophenol. Yield parameters obtained at harvest [soybean grain yield (SGY, $\mathrm{kg} \mathrm{ha}^{-1}$ ), adjusted to $13 \%$ moisture; total grain $\mathrm{N}$ content ( $\mathrm{TGN}, \mathrm{kg} \mathrm{N} \mathrm{ha}^{-1}$ ); percentage grain $\mathrm{N}\left(\% \mathrm{GN}, \mathrm{g} \mathrm{kg}^{-1}\right.$ )] are presented in our accompanying study (Hungria et al., 2014), and were used in this study for the correlation analyses with individual microbial variables and with the pooled variables, denominated as soil microbial variables (SMV).

\subsection{Statistical analyses}

Prior to the analysis of variance (ANOVA), data were tested for normality of variables and uniformity of variance (SAS Institute, 1999). After that, data from season $2005 / 2006$ were submitted to means contrast analysis, to compare the effects of the transgenic trait (Contrast 1), type of herbicide in transgenic cultivars (Contrast 2), and weed-management strategies (Contrast 3) on soil microbiological variables (SMV), as follows: Contrast 1 , transgenic vs. non-transgenic (only conventional herbicide and hand-weed control treatments) $[(\mu \mathrm{T} 2+\mu \mathrm{T} 4) / 2]-[(\mu \mathrm{T} 3+\mu \mathrm{T} 5) / 2]$; Contrast 2 , transgenic with glyphosate vs. transgenic with conventional herbicide $[\mu \mathrm{T} 1]-[\mu \mathrm{T} 2]$; and Contrast 3 , transgenic with glyphosate vs. non-transgenic with conventional herbicide $[\mu \mathrm{T} 1]-[\mu \mathrm{T} 3]$, where $\mathrm{T} 1, \mathrm{~T} 2, \mathrm{~T} 3, \mathrm{~T} 4, \mathrm{~T} 5$ represent the treatments and $\mu$ represents the means. Contrast significance was assessed by the Student's $t$ test $(p \leq 0.05)$. The same contrasts were used to analyze MB-C and MB-N data, averaged over the 2004/2005 and 2005/2006 seasons.

In addition, we used a multivariate analysis to evaluate the effects of the transgenic event and herbicides on soil SMV, described by the analysis of four pooled variables (MB-C, MB-N, GLU, PHO).
A two-dimensional ordination of samples in the space of microbial variables, representing differences in SMV among treatments, was attained by non-metric multidimensional scaling (NMS, Sokal, 1979), with Sorensen distances. Prior to analysis, data were standardized by totals within each variable (option "relativization by column totals" in PC-ORD v.6.0) to eliminate the differences in the expression units between variables. The ordination was run in the autopilot mode, using the "slow and thorough" option in the PCORD v.6.0 software (McCune and Mefford, 2011). The number of dimensions to be interpreted was selected considering the criteria of stress and stability of the graphical solutions.

Variations in the SMV among the different sites were characterized by Pearson correlation between the sample scores on the NMS Axes 1 and 2 and the values of microbiological variables. Correlation analyses were also performed to describe the relationship between productivity components (SGY, \%NG and TNG) and SMV NMS scores.

A blocked multiresponse permutation procedure (blockedMRPP, Mielke and Berry, 2000) was employed to test the hypotheses of no effect of transgenic trait, herbicide type, and weed-management strategy on SMV, using the same three contrasts described for the univariate analysis as "grouping variables" and sites as "blocking variables." Because PC-ORD v.6.0 permits only two levels of explanatory variables (grouping and blocking variables; in our case, contrasts and regions, respectively) for blocked-MRPP the mean values among replicates (blocks) from each treatment were used. This analysis approach allowed us to test the hypotheses after considering the differences in SMV between regions. In all cases, Sorensen distance measure was used. Values of $p$ associated with test statistics $(T)$ were determined by numerical integration of the Pearson type III distribution. All multivariate tests were performed using the statistical program PC-ORD v. 6.0 (McCune and Mefford, 2011).

For each tested contrast, MB-C and MB-N were modeled using sums of squares multivariate regression tree (SS-MRT) models (De'Ath, 2002), with site, season, cultivar, and contrast treated as categorical explanatory variables. This analysis allowed us to evaluate the effect size of each contrast on MB-C and MB-N relative to those of site, season and cultivar. A series of 20- to 10-fold cross-validations (Breiman et al., 1984) was run to choose the most frequently occurring (modal) tree size with a minimum error rate (De'Ath and Fabricius, 2000). The final tree size was chosen using the 1-SE (standard error) rule (Breiman et al., 1984), which results in a tree smaller than that suggested by the minimum crossvalidated-error rate (at most 1-SE). A library of S-Plus functions for tree routines (RPART: Recursive partitioning), developed by $\mathrm{T}$. Therneau (unpublished data), was used for all SS-MRT models. SPlus (version 4.0) statistical software (Mathsoft, 1999) was used for these analyses.

Multivariate techniques (NMS and MRPP) used to evaluate the response of the four pooled variables (SMV) to the factors tested were carried out only with data from season 2005/2006 and cultivar C1.

\section{Results}

3.1. Impact of transgenic soybean, glyphosate and weed-management strategy on soil-microbiological variables

First, results of season 2005/2006 are presented, where the soil microbiological condition was assessed from microbial biomasscarbon (MB-C) and -nitrogen (MB-N), beta-glucosidase (GLU) and acid phosphatase (PHO) activities, since the soil enzyme activities were not measured during the earlier seasons. Following, results from MB-C and MB-N in two cropping seasons (2004/2005 and 
Table 1

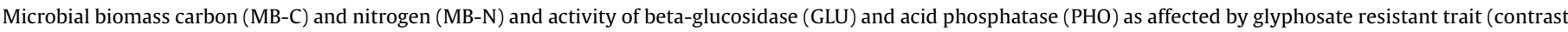
1 ) in soybean cultivars grown in six major producing sites in Brazil in the crop season of 2005/2006.

\begin{tabular}{|c|c|c|c|c|c|}
\hline \multirow{2}{*}{$\begin{array}{l}\text { Site } \\
\text { Passo Fundo }\end{array}$} & \multirow{2}{*}{$\begin{array}{l}\text { Contrast } \\
\text { Transgenic }\end{array}$} & \multirow{2}{*}{$\begin{array}{l}\text { MB-C } \\
{\mathrm{mgC} \mathrm{kg}^{-1} \text { soil }}\end{array}$} & \multirow{2}{*}{$\begin{array}{l}\text { MB-N } \\
\mathrm{mg} \mathrm{N} \mathrm{kg}^{-1} \text { soil }\end{array}$} & \multicolumn{2}{|c|}{$\mu \mathrm{g}$ p-nitrophenol g ${ }^{-1}$ soil h $^{-1}$} \\
\hline & & & & 126.33 & 497.27 \\
\hline & Non-transgenic & 268.03 & 15.13 & 135.66 & 507.92 \\
\hline & $p$ & ns & ns & ns & ns \\
\hline \multirow[t]{3}{*}{ Ponta Grossa } & Transgenic & 153.68 & 17.94 & 115.35 & 453.94 \\
\hline & Non-transgenic & 141.82 & 19.83 & 106.95 & 473.97 \\
\hline & $p$ & ns & ns & ns & ns \\
\hline \multirow[t]{3}{*}{ Londrina } & Transgenic & 248.00 & 24.21 & 150.54 & 423.69 \\
\hline & Non-transgenic & 253.37 & 25.48 & 155.46 & 441.63 \\
\hline & $p$ & ns & ns & ns & ns \\
\hline \multirow[t]{3}{*}{ Uberaba } & Transgenic & 152.75 & 7.46 & 54.16 & 407.11 \\
\hline & Non-transgenic & 121.92 & 8.16 & 48.83 & 450.20 \\
\hline & $p$ & & ns & ns & \\
\hline \multirow[t]{3}{*}{ Planaltina } & Transgenic & 224.09 & 33.18 & 138.91 & 521.83 \\
\hline & Non-transgenic & 239.80 & 33.25 & 152.30 & 533.62 \\
\hline & $p$ & ns & ns & ns & ns \\
\hline \multirow[t]{3}{*}{ Luiz Eduardo Magalhães } & Transgenic & 179.04 & 15.05 & 45.79 & 281.95 \\
\hline & Non-transgenic & 178.44 & 11.95 & 42.31 & 264.10 \\
\hline & $p$ & ns & ns & ns & ns \\
\hline
\end{tabular}

${ }^{*} p<0.05$.

** $p<0.01$.

2005/2006) are presented, allowing us to evaluate the effects of the transgene, crop season, site and cultivar on these two microbiological variables.

Except for a few cases, soil microbiological parameters evaluated in 2005/2006 were not affected by either the transgenic trait (Table 1), type of herbicide (Table 2), or weed-management method (Table 3). Yet, in these few cases, effects were not consistent in terms of specific treatments and were dependent on the type of variable and site. When compared to their nearly isogenic non-transgenic counterparts, transgenic cultivars increased $\mathrm{MB}-\mathrm{C}$ $(+25 \%)$ and decreased PHO values $(-11 \%)$ at Uberaba (Table 1$)$.

There were no differences between types of herbicide in terms of MB-N, regardless of the site. Compared with glyphosate, conventional herbicides resulted in higher MB-C (+24\%) at Uberaba, GLU at Passo Fundo (+25\%), and PHO at Planaltina (+14\%), but in lower PHO at Londrina $(-13 \%)$ (Table 2$)$.

Compared with the weed-management strategy based on nontransgenic cultivars and conventional herbicides, the combined use of glyphosate and RR soybeans resulted in higher PHO (+12\%) at Londrina and MB-C $(+22 \%)$ at Uberaba. However, the opposite was true for GLU (-51\%) and PHO (-25\%) at Passo Fundo, PHO at Uberaba ( $-19 \%)$, and MB-N at L.E. Magalhães $(-36 \%)$ (Table 3 )

When the two seasons (2004/2005 and 2005/2006) were analyzed together, no effects on MB-C and MB-N were observed for any of the microbial contrasts evaluated (Table 4).

A two-dimensional NMS graph represented $97 \%$ of the variability of the soil microbial variables (SMV), described by the analysis of four pooled biological variables (MB-C, MB-N, GLU and PHO) (Fig. 2).

Table 2

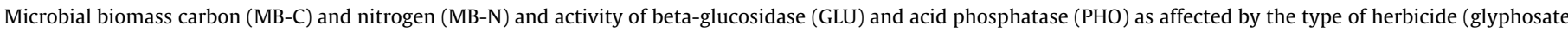
vs. conventional herbicides) used to control weeds (contrast 2) in RR soybean crops in six major producing sites in Brazil in the crop season of $2005 / 2006$.

\begin{tabular}{|c|c|c|c|c|c|}
\hline Site & Contrast & 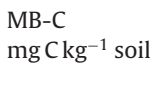 & $\begin{array}{l}\text { MB-N } \\
\mathrm{mg} \mathrm{N} \mathrm{kg}^{-1} \text { soil }\end{array}$ & $\begin{array}{l}\text { GLU } \\
\mu g \text { p-nitrophenol } \\
g^{-1} \text { soil h}^{-1}\end{array}$ & PHO \\
\hline Passo Fundo & $\begin{array}{l}\text { Transgenic with glyphosate } \\
\text { Transgenic with conventional herbicide } \\
p\end{array}$ & $\begin{array}{l}298.86 \\
258.10 \\
\text { ns }\end{array}$ & $\begin{array}{l}12.74 \\
13.34 \\
\text { ns }\end{array}$ & $\begin{array}{l}99.13 \\
123.67\end{array}$ & $\begin{array}{l}420.11 \\
478.03 \\
\text { ns }\end{array}$ \\
\hline Ponta Grossa & $\begin{array}{l}\text { Transgenic with glyphosate } \\
\text { Transgenic with conventional herbicide } \\
p\end{array}$ & $\begin{array}{l}161.51 \\
148.41 \\
\text { ns }\end{array}$ & $\begin{array}{l}18.01 \\
17.24 \\
\text { ns }\end{array}$ & $\begin{array}{l}89.66 \\
112.81 \\
\text { ns }\end{array}$ & $\begin{array}{l}461.49 \\
512.64 \\
\text { ns }\end{array}$ \\
\hline Londrina & $\begin{array}{l}\text { Transgenic with glyphosate } \\
\text { Transgenic with conventional herbicide } \\
p\end{array}$ & $\begin{array}{l}274.57 \\
240.47 \\
\text { ns }\end{array}$ & $\begin{array}{l}27.31 \\
24.79 \\
\text { ns }\end{array}$ & $\begin{array}{l}144.09 \\
134.59 \\
\text { ns }\end{array}$ & $\begin{array}{l}484.03 \\
430.16\end{array}$ \\
\hline Uberaba & $\begin{array}{l}\text { Transgenic with glyphosate } \\
\text { Transgenic with conventional herbicide } \\
p\end{array}$ & $\begin{array}{l}164.14 \\
203.69\end{array}$ & $\begin{array}{l}6.03 \\
7.55 \\
\text { ns }\end{array}$ & $\begin{array}{l}49.68 \\
56.22 \\
\text { ns }\end{array}$ & $\begin{array}{l}392.47 \\
431.85 \\
\text { ns }\end{array}$ \\
\hline Planaltina & $\begin{array}{l}\text { Transgenic with glyphosate } \\
\text { Transgenic with conventional herbicide } \\
p\end{array}$ & $\begin{array}{l}252.86 \\
229.57 \\
\text { ns }\end{array}$ & $\begin{array}{l}33.12 \\
34.46 \\
\text { ns }\end{array}$ & $\begin{array}{l}155.76 \\
148.71 \\
\text { ns }\end{array}$ & $\begin{array}{l}530.03 \\
604.41\end{array}$ \\
\hline Luiz Eduardo Magalhães & $\begin{array}{l}\text { Transgenic with glyphosate } \\
\text { Transgenic with conventional herbicide } \\
p\end{array}$ & $\begin{array}{l}235.53 \\
204.62 \\
\text { ns }\end{array}$ & $\begin{array}{l}15.95 \\
17.35 \\
\text { ns }\end{array}$ & $\begin{array}{l}48.17 \\
48.50 \\
\text { ns }\end{array}$ & $\begin{array}{l}273.80 \\
303.10 \\
\text { ns }\end{array}$ \\
\hline
\end{tabular}

\footnotetext{
${ }^{*} p<0.05$
}

${ }^{* *} p<0.01$. 
Table 3

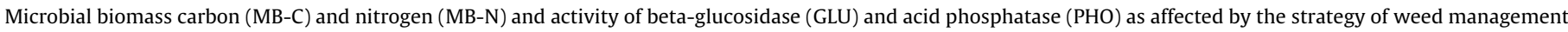

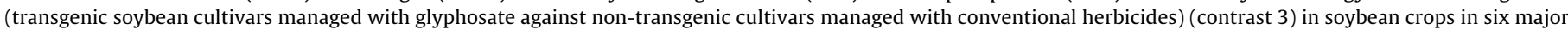
producing sites in Brazil in the crop season of 2005/2006.

\begin{tabular}{|c|c|c|c|c|c|}
\hline Site & Contrast & $\begin{array}{l}\text { MB-C } \\
\mathrm{mgC}^{-1} \text { soil }\end{array}$ & $\begin{array}{l}\text { MB-N } \\
\mathrm{mg} \mathrm{N} \mathrm{kg}^{-1} \text { soil }\end{array}$ & $\begin{array}{l}\text { GLU } \\
\mu \mathrm{g} \text { p-nitrophenol } \\
\mathrm{g}^{-1} \text { soil h }^{-1}\end{array}$ & PHO \\
\hline Passo Fundo & $\begin{array}{l}\text { Transgenic with glyphosate } \\
\text { Non-transgenic with conventional herbicide } \\
p\end{array}$ & $\begin{array}{l}298.86 \\
267.47 \\
\text { ns }\end{array}$ & $\begin{array}{l}12.74 \\
16.13 \\
\text { ns }\end{array}$ & $\begin{array}{l}99.13 \\
149.26\end{array}$ & $\begin{array}{l}420.11 \\
526.88\end{array}$ \\
\hline Ponta Grossa & $\begin{array}{l}\text { Transgenic with glyphosate } \\
\text { Non-transgenic with conventional herbicide } \\
p\end{array}$ & $\begin{array}{l}161.51 \\
148.30 \\
\text { ns }\end{array}$ & $\begin{array}{l}18.01 \\
20.77 \\
\text { ns }\end{array}$ & $\begin{array}{l}89.66 \\
107.57 \\
\text { ns }\end{array}$ & $\begin{array}{l}461.49 \\
507.81 \\
\text { ns }\end{array}$ \\
\hline Londrina & $\begin{array}{l}\text { Transgenic with glyphosate } \\
\text { Non-transgenic with conventional herbicide } \\
p\end{array}$ & $\begin{array}{l}274.57 \\
290.37 \\
\text { ns }\end{array}$ & $\begin{array}{l}27.31 \\
26.84 \\
\text { ns }\end{array}$ & $\begin{array}{l}144.09 \\
153.08 \\
\text { ns }\end{array}$ & $\begin{array}{l}484.03 \\
433.32\end{array}$ \\
\hline Uberaba & $\begin{array}{l}\text { Transgenic with glyphosate } \\
\text { Non-transgenic with conventional herbicide } \\
p\end{array}$ & $\begin{array}{l}164.14 \\
134.68\end{array}$ & $\begin{array}{l}6.03 \\
7.04 \\
\text { ns }\end{array}$ & $\begin{array}{l}49.67 \\
52.64 \\
\text { ns }\end{array}$ & $\begin{array}{l}392.47 \\
465.72\end{array}$ \\
\hline Planaltina & $\begin{array}{l}\text { Transgenic with glyphosate } \\
\text { Non-transgenic with conventional herbicide } \\
p\end{array}$ & $\begin{array}{l}252.86 \\
248.85 \\
\text { ns }\end{array}$ & $\begin{array}{l}33.12 \\
34.14 \\
\text { ns }\end{array}$ & $\begin{array}{l}155.76 \\
163.35 \\
\text { ns }\end{array}$ & $\begin{array}{l}530.03 \\
551.09 \\
\text { ns }\end{array}$ \\
\hline Luiz Eduardo Magalhães & $\begin{array}{l}\text { Transgenic with glyphosate } \\
\text { Non-transgenic with conventional herbicide } \\
p\end{array}$ & $\begin{array}{l}216.38 \\
248.39 \\
\text { ns }\end{array}$ & $\begin{array}{l}6.25 \\
9.72\end{array}$ & $\begin{array}{l}48.17 \\
44.14 \\
\text { ns }\end{array}$ & $\begin{array}{l}273.80 \\
251.33 \\
\text { ns }\end{array}$ \\
\hline
\end{tabular}

${ }_{* *}^{*} p<0.05$

Table 4

MB-C and MB-N as affected by RR trait in soybean cultivars (transgenic $\times$ nontransgenic), the type of herbicide (transgenic with glyphosate $\times$ transgenic with conventional herbicide) used to control weeds in areas with transgenic cultivars, and strategy of weed management (glyphosate + RR cultivars vs. conventional herbicide + non-RR cultivars) in soybean in the crop seasons of 2004/2005 and 2005/2006 in six main producing sites in Brazil.

\begin{tabular}{lll}
\hline Contrast & $\begin{array}{l}\mathrm{MB}-\mathrm{C} \\
\mathrm{mgC} \mathrm{kg}^{-1} \text { soil }\end{array}$ & $\begin{array}{l}\mathrm{MB}-\mathrm{N} \\
\mathrm{mg} \mathrm{N} \mathrm{kg}^{-1} \text { soil }\end{array}$ \\
\hline $\begin{array}{l}\text { Transgenic } \times \text { Non-transgenic } \\
\text { Transgenic }\end{array}$ & 314.82 & 32.09 \\
Non-transgenic & 308.40 & 32.09 \\
$P$ & $\mathrm{~ns}$ & $\mathrm{~ns}$ \\
Transgenic with glyphosate $\times$ Transgenic with conventional herbicide \\
Transgenic with glyphosate & 329.38 & 31.98 \\
Transgenic with conventional herbicide & 323.00 & 32.48 \\
$P$ & $\mathrm{~ns}$ & $\mathrm{~ns}$ \\
Transgenic with glyphosate $\times$ Non-transgenic with conventional herbicide \\
Transgenic with glyphosate & 329.38 & 31.98 \\
Non-transgenic with conventional & 317.05 & 31.37 \\
$\quad$ herbicide & $\mathrm{ns}$ & $\mathrm{ns}$ \\
$P$ & &
\end{tabular}

Table 5

Correlation coefficients $(r$ ) of soil microbial variables (SMV) with non-metric multidimensional scaling (NMS) ordination axis.

\begin{tabular}{llr}
\hline & Axis 1 & Axis 2 \\
\hline Microbial biomass carbon & 0.291 & $0.984^{* * *}$ \\
Microbial biomass nitrogen & $0.835^{* * *}$ & -0.016 \\
Beta-glucosidase activity & $0.926^{* * *}$ & 0.530 \\
Acid phosphatase activity & $0.781^{* * *}$ & 0.278 \\
\hline
\end{tabular}

*** $p<0.001$.

Axis 1 represented most of the total variability (72\%), whereas only a minor portion (25\%) was represented by Axis 2. GLU and PHO activities and MB-N were predominantly correlated with Axis 1, whereas MB-C was correlated with Axis 2 (Table 5). SMV clearly shifted between the six sites $(p<0.001)$, possibly related to the contrasting chemical properties of the soils (Table S1). The arrangement of soil samples from different sites along axis 1 of SMV was strongly and positively correlated with $\mathrm{Al}+\mathrm{H}(r=0.89, p<0.01)$ and CEC $(r=0.81, p<0.05)$. Therefore, shifts in SMV from L. E. Magalhães toward Planaltina were associated with increases in MB-N,

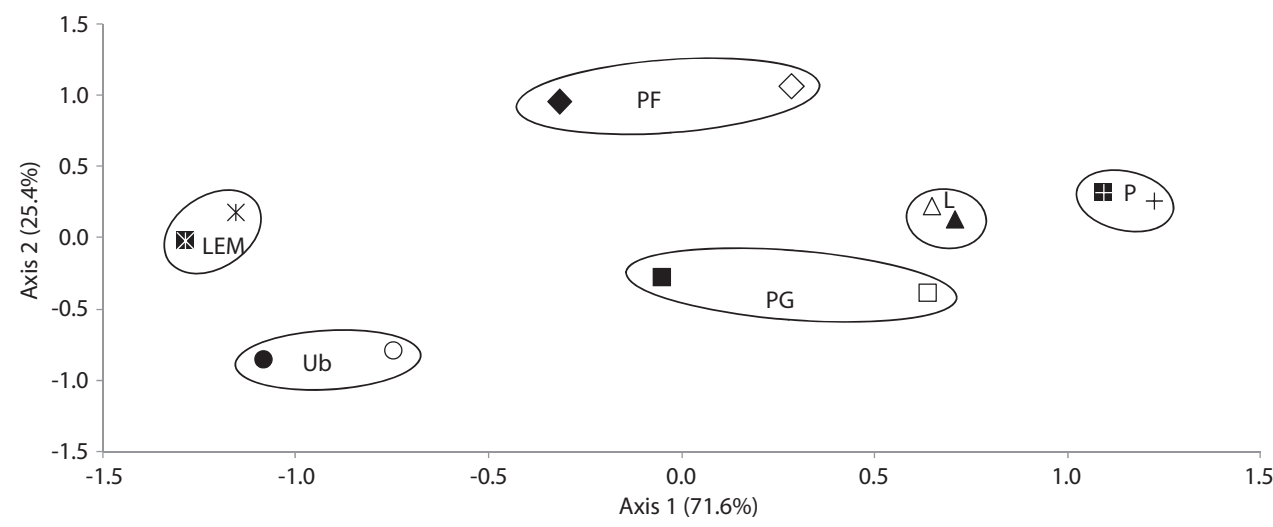

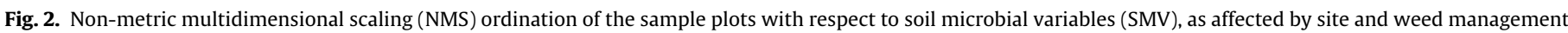

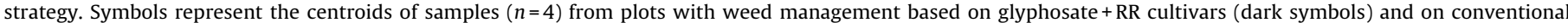

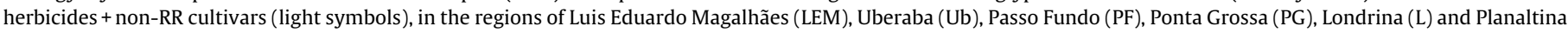
(P). $p$ value for comparisons of SMV between the two weed management strategies was 0.052 , after considering differences due to sites. 
Table 6

Percentage of the data variability explained by the tree model for microbial biomasscarbon (MB-C) and nitrogen (MB-N) in contrasts 1, 2 and 3, as a function of site, year of sampling, cultivar and the tested contrast. Crop seasons of 2004/2005 and $2005 / 2006$.

\begin{tabular}{|c|c|c|c|c|c|c|}
\hline \multirow[t]{2}{*}{ Effect } & \multicolumn{2}{|c|}{ Contrast 1} & \multicolumn{2}{|c|}{ Contrast 2} & \multicolumn{2}{|c|}{ Contrast 3} \\
\hline & MB-C & MB-N & MB-C & MB-N & MB-C & MB-N \\
\hline Site & 29.43 & 27.53 & 31.86 & 38.63 & 30.90 & 36.10 \\
\hline Crop season & 26.92 & 30.03 & 22.32 & 25.79 & 20.97 & 24.20 \\
\hline Cultivar & 13.97 & 16.49 & 17.13 & 12.96 & 20.32 & 14.51 \\
\hline Contrast & 0.18 & 0.56 & 0.88 & 0.62 & 1.71 & 4.89 \\
\hline Explained \% & 70.50 & 74.60 & 72.20 & 78.00 & 73.90 & 79.70 \\
\hline
\end{tabular}

Contrast 1: transgenic vs. non-transgenic; contrast 2: transgenic with glyphosate vs. transgenic with conventional herbicide; contrast 3: transgenic with glyphosate vs. non-transgenic with conventional herbicide.

GLU and PHO, which in turn, were correlated with increments in $\mathrm{Al}+\mathrm{H}$ and CEC. Also, variations in SMV between regions along axis 2 were correlated with $\mathrm{Ca}+\mathrm{Mg}(r=0.85, p<0.05)$ and $\mathrm{SB}(r=0.81$, $p<0.05)$.).

However, according to blocked-MRPP, SMV was not affected by transgenic traits $\left(P_{\text {Contrast } 1}=0.376\right)$; type of herbicide in transgenic cropping $\left(P_{\text {Contrast } 2}=0.249\right)$; or weed-management strategy $\left(P_{\text {Contrast } 3}=0.052\right)$, after considering differences associated with the six experimental sites. Although the effects of weed-management strategies were marginally non-significant $(p=0.052)$, it is noteworthy that the pattern of change in SMV was, except for Londrina, the same for all sites, with samples from conventional herbicides with non-RR cultivars placed at the right side of samples with glyphosate and RR-cultivar-based management (Fig. 2). These shifts are in agreement with the significant increases observed in response to the use of conventional herbicides with non-RR cultivars in MB-N at Luiz Eduardo Magalhães, in PHO in Uberaba, PHO and GLU in Passo Fundo, and with trends of increments in MB-N, PHO and GLU in the majority of the evaluated sites (Table 3), especially in Ponta Grossa, Passo Fundo, Uberaba, and Planaltina.

The results of the tree model selected to measure the contribution of different factors (site, cropping season, cultivar and contrast) on the data variability of MB-C and MB-N in 2004/2005 and 2005/2006 for each contrast tested are shown in Table 6. It was verified that variability in the MB-C and MB-N data can be explained mainly by the factor "site" (from 28\% to 36\%), followed by "crop season" (from 21\% to $30 \%$ ) and "cultivar" (from $13 \%$ to $20 \%$ ). On the other hand, the tested contrasts are responsible for only a small fraction of MB-C and MB-N variability (from $0.2 \%$ to 4.9\%). Therefore, site, cropping season and cultivar were far more influential on soil MB-C and MB-N than the use of a transgenic crop or glyphosate.
Table 7

Correlation coefficients between the soil microbial variables (SMV) and soybean yield from five sites in Brazil. Crop season of 2005/2006.

\begin{tabular}{lll}
\hline & SGY & $\% \mathrm{GN}$ \\
\hline MB-C & -0.09 & 0.16 \\
MB-N & $0.34^{* * * *}$ & $-0.40^{* * *}$ \\
GLU & $0.31^{* * *}$ & $-0.55^{* * *}$ \\
PHO & $0.58^{* * *}$ & $-0.67^{* * *}$
\end{tabular}

MB-C, carbon microbial biomass; MB-N, nitrogen microbial biomass; GLU, betaglucosidase; PHO, acid phosphatase; SGY, soybean grain yield; \%GN, \% of grain nitrogen. Soybean grain yield data from Passo Fundo were lost due a drought event. ${ }^{* * *} p<0.001$.

\subsection{Correlation between the soil microbial variables (SMV) and soybean grain yield}

Highly significant correlations $(p<0.001)$ were observed between soybean yield parameters SGY and \%GN with Axes 1 of NMS ordination describing SMV (Fig. $3 \mathrm{~A}$ and B). These correlations were positive and significant between SGY and MB-N, GLU, and PHO. Conversely, the correlations were negative and significant between \%NG and these three microbiological variables, and non-significant correlations were found with MB-C (Table 7).

\section{Discussion}

Despite the benefits associated with transgenic soybean, such as increased grain yield and reduction of agrochemical use, concerns about the implications of the transgenes on human health and environmental safety are often raised (Cerdeira et al., 2007). In relation to the soil environment, it is well known that soil microorganisms play key roles that affect soil quality, justifying the need for continuous studies to monitor the effects of disturbances, with an emphasis on those associated with new agricultural technologies and pesticides (e.g. Kaschuk et al., 2010, 2011). The quantification of soil microbial biomass $-\mathrm{C}$ and $\mathrm{N}-\mathrm{is}$ justified in the present study because they are sensitive variables to evaluate environmental impacts. In fact, Souza et al. (2008a,b) in an extensive study performed in Brazil, found soil microbial biomass to be part of a minimum dataset to assess the impacts of new technologies in agriculture. Similarly, soil enzymes play an important role in the nutrient cycling and are thus useful tools to evaluate soil microbial activity, since most soil enzymes are released by microorganisms (Stott et al., 2010; Lopes et al., 2013).

In addition, soil microbial parameters may be useful indicators of sustainability and yield; indeed, direct relations between crop yield and microbial biomass (e.g. Hungria et al., 2009; Silva et al., 2010) and soil enzymes (Zhang et al., 2012; Lopes et al., 2013) have been reported by other authors and were confirmed in our
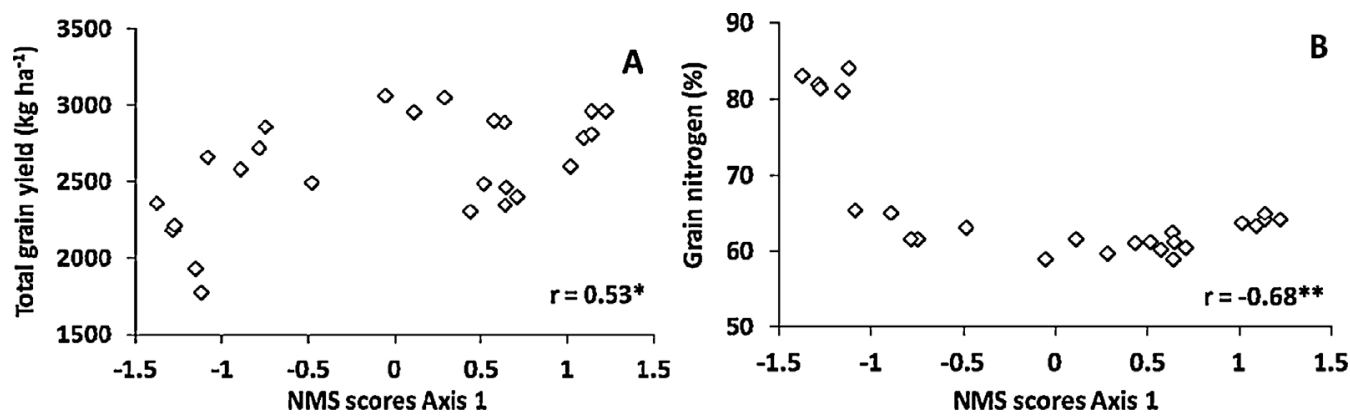

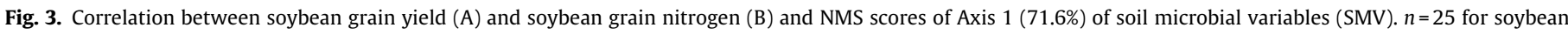
grain yield and grain nitrogen content. Data from Passo Fundo were lost due to a drought event. ${ }^{*} p<0.005,{ }^{* *} p<0.0005$. Crop season of $2005 / 2006$. 
study, with positive, significant correlations between three microbial parameters (MB-N, GLU and PHO) and soybean yield.

Our study has shown that glyphosate-resistance in soybean had no impact on soil microbial variables, assessed during one (2004/2005) or two consecutive cropping seasons (2004/2005 and 2005/2006), in agreement with other studies that showed little or no effect on soil microbial communities (Bruinsma et al., 2003; Motavalli et al., 2004; Liu et al., 2008; Böhm and Rombaldi, 2010; Weinert et al., 2010). Another transgenic soybean carrying the ahas gene-which confers resistance to herbicides of the imidazolinone group-also had no impact on soil microbial biomass compared to the non-transgenic parental cultivar treatment, in field trials carried out in six sites in Brazil for three cropping seasons (Souza et al., 2013).

We found that soil microbial biomass was more affected by site, cropping season and soybean cultivar than the transgenic trait. Although changes in soil microbial variables due to transgenic plants have been reported (Dunfield and Germida, 2001; Wei et al., 2006), the effects have usually been minor when compared to those related to natural variability and environmental factors, such as soil type, site, climate, time of year and tillage practice (Lottmann et al., 1999; Lukow et al., 2000; Dunfield and Germida, 2004; Griffiths et al., 2007). Even when changes related to a transgene were detected, they were short-lived and were absent from subsequent evaluations (Gyamfi et al., 2002; Dunfield and Germida, 2003; Mulder et al., 2006). According to Hart et al. (2009), EPSPS occurs naturally in agricultural soils, produced by the common soil bacterium Agrobacterium tumefaciens, therefore its effects-when produced by RR soybean-on soil microbial populations are likely to be minor in comparison with modifications that introduce novel or detrimental proteins into the soil.

In some of the findings of no effect of transgenic RR soybean on microbial communities, impacts of the herbicide glyphosate have been reported. Dallmann et al. (2010), in a field experiment performed in southern Brazil in the 2008/2009 crop season did not detect differences in fungal densities between soils planted with one transgenic (BRS 243RR) and one non-transgenic (BRS Cambona) soybean cultivar; however, glyphosate decreased fungal populations. The same authors reported that, under high application of glyphosate (1920 and $3840 \mathrm{~g}$ a.i. ha ${ }^{-1}$ ), metabolic quotient $\left(q \mathrm{CO}_{2}\right)$ was higher, as a result of increased $\mathrm{CO}_{2}$ production without change in MB-C. The effects of glyphosate on soil microorganisms depend on the dosage, soil texture and organic matter content (Giesy et al., 2000), as well as the site, cropping conditions and time at which it is applied (Wallis et al., 2010). Nevertheless, in our study, no such effects were detected, in agreement with the results of other studies reporting no impact of glyphosate on microbial biomass (Liphadzi et al., 2005; Pereira et al., 2008; Bohm et al., 2011). Zilli et al. (2008), in a greenhouse experiment, using a Brazilian Oxisol (Latossolo vermelho distroférrico, clayey texture), also found no effect of glyphosate on soil microbial biomass, and suggested that this may be explained by adsorption to colloids. Similarly, the herbicide would not be available to microorganisms as sources of C, N or P (Van Eerd et al., 2003); furthermore, degradation by hydrolysis and photolysis (Giesy et al., 2000) may contribute to reduced toxicity for soil microorganisms.

In relation to the weed management, we found no differences in the effect of transgenic soybean and glyphosate vs. non-transgenic soybean and conventional herbicides. Similarly, in the study with the transgenic ahas gene, differences were not detected between the treatments of transgenic soybean and imidazolinone vs. non-transgenic soybean with conventional herbicide (Souza et al., 2013). Regarding to glyphosate resistant cropping system, under field conditions in southern Brazil, in the cropping season of $2007 / 2008$, Bohm et al. (2011) observed no changes on soil microbial biomass in the comparison between one transgenic soybean BRS 244RR with glyphosate, and one conventional soybean BRS 154 treated with the conventional herbicide imazethapyr.

It is important to highlight that the mentioned studies evaluating the effects of transgenic plants and/or glyphosate on soil microorganisms were conducted either under greenhouse conditions (Zilli et al., 2008), or under field condition in only one cropping season and one site (Dallmann et al., 2010; Bohm et al., 2011). In addition, the comparisons did not consider pairs of transgenic and the respective parental non-transgenic cultivar. In our study, treatments were evaluated at six field sites differing in edaphoclimatic conditions, during two consecutive cropping seasons (for MB-C and MB-N), and considering three pairs of transgenic vs. the nearly isogenic parental non-transgenic cultivar, giving higher credibility to the results that showed no effects of weed-management strategies on soil microbial variables.

Soil microbial biomass is composed by numerous microbial groups in constant interaction with the ecosystem, and in our study the introduction of transgenic plants and glyphosate application to the system did not change the microbial biomass as a whole. However, it is important to point out that our findings are valid for our specific case where few microbial attributes were evaluated in a maximum of two crop seasons. Further and long-term studies are needed using larger sets of microbial variables to confirm that the transgenic trait and the glyphosate application do not affect soil microorganisms.

\section{Concluding remarks}

Overall, soil microbial communities-evaluated in this study in terms of microbial biomass (MB-C and MB-N), and activities of acid phosphatase and beta-glucosidase-showed no differences in the comparisons of: RR transgenic $\times$ nearly isogenic parental non-transgenic cultivars; glyphosate $\times$ conventional herbicides; or RR soybean with glyphosate $\times$ conventional soybean and herbicide management. Moreover, where impacts on individual microbiological properties were observed, they were not consistently obtained with a specific treatment, but rather correlated with site, crop season and/or cultivar.

\section{Acknowledgments}

Authors are thankful to the Embrapa' researchers Dr. Ana Claudia Barneshe de Oliveira, Dr. Neylson Eustáquio Arantes and Dr. Paulo Fernando Bertagnolli for help in the field experiments in Luiz Eduardo Magalhães, Uberaba and Passo Fundo, respectively. They also thank Dr. Carlos Arrabal Arias for helping in seed supply and Dr. Maria Cristina Neves de Oliveira for help in the statistics. Authors are thankful to both reviewers of FCR who greatly contributed to the improvement of the paper. Authors also thank to the field technical support of José Zucca de Morais and Rubson Natal Ribeiro Sibaldelli, to the field workers of the Microbiology team, and to the laboratory support of Rinaldo Benedito Conceição in all experiments. Finally, we thank to Dr. Allan R.J. Eaglesham for English correction and suggestions on the manuscript. The project was partially financed by FINEP (Financiadora de Estudos e Projetos), and the research group is supported by CNPq (National Council for Scientific and Technological Development), Project Repensa (562008/2010-1) and Universal (470515/2012-0). Prior to submission the manuscript was analyzed and approved for publication by the Editorial Board of Embrapa Soja as manuscript 183/2013. Authors either are fellows or received fellowships from CNPq and CAPES/Fundação Araucária. 


\section{References}

Araujo, A.F.S., Monteiro, R.T.R., Abarkeli, R.B., 2003. Effect of glyphosate on the microbial activity of two Brazilian soils. Chemosphere 52, 799-804.

Balota, E.L., Nogueira, M.A., Mendes, I.C., Hungria, M., Fagotti, D.S.L., Melo, G.M.P., Souza, R.C., Melo, W.J., 2013. Enzimas e seu papel na qualidade do solo. In: Araújo, A.P., Alves, B.J.R. (Eds.), Tópicos em ciência do solo, vol. 8. Sociedade Brasileira de Ciência do Solo, Viçosa, Brazil, pp. 189-249.

Bandick, A.K., Dick, R.P., 1999. Field management effects on soil enzyme activities. Soil Biol. Biochem. 31, 1471-1479.

Bartlett, R.J., Ross, D.N., 1988. Colorimetric determination of oxidizable carbon in acid soil solutions. Soil Sci. Soc. Am. J 52, 1191-1192.

Böhm, G.M.V., Rombaldi, C.V., 2010. Genetic transformation and the use glyphosate on soil microbial, biological nitrogen fixation, quality and safety of genetically modified soybean. Cienc. Rural 40, 213-221.

Bohm, G.M.V., Castilhos, D., Pigosso, G., Trichez, D., Rombaldi, C., 2007. Efeito do controle de plantas concorrentes na biomassa e atividade microbiana em Planossolo cultivado com soja BRS 244RR. Rev. Bras. Agrocienc. 13, 503-508.

Bohm, G.M.V., Scheneider, L., Castilhos, D., Agostinetto, D., Rombaldi, C.V., 2011. Weed control, biomass and microbial metabolism of soil depending on the application of glyphosate and imazethapyr on crop soybeans. Semina. Cienc. Agrar. 32, 919-929.

Breiman, L., Friedman, J.H., Olshen, R.A., Stone, C.G., 1984. Classification and Regression Tree. Wadsworth International Group, Belmont, CA, USA, 358 pp.

Brookes, P.C., Landman, A., Pruden, G., Jenkinson, D.S., 1985. Chloroform fumigation and the release of soil nitrogen: A rapid direct extraction method to measure microbial biomass nitrogen in soil. Soil Biol. Biochem. 17, 837-842.

Bruinsma, M., Kowalchuk, G.A., van Veen, J.A., 2003. Effects of genetically modified plants on microbial communities and processes in soil. Biol. Fertil. Soils 37, 329-337.

Cerdeira, A.L., Gazziero, D.L., Duke, S.O., Matallo, M.B., Spadotto, C.A., 2007. Review of potential environmental impacts of transgenic glyphosate-resistant soybean in Brazil. J. Environ. Sci. Health B: Pestic. Food Contam. Agric. Wastes 42, 539-549.

Dallmann, C.M., Scheneider, L., Bohm, G.M.B., Kuhn, C.R., 2010. Impacto da aplicação de glifosato na microbiota do solo cultivado com soja geneticamente modificada. Ver. Thema 7, 1-11.

De'Ath, G., 2002. Multivariate regression trees: a new technique for modeling species-environment relationships. Ecology 83, 1105-1117.

De'Ath, G., Fabricius, K.E., 2000. Classification and regression trees: a powerful yet simple technique for ecological data analysis. Ecology 81, 3178-3192.

Donegan, K.K., Palm, C.J., Fieland, V.J., Porteus, L.A., Ganio, L.M., Schaller, D.L., Bucao, L.Q., Seidler, R.J., 1995. Changes in levels, species and DNA fingerprints of soil microorganisms associated with cotton expressing the Bacillus thuringiengis var. kurstaki endotoxin. Appl. Soil Ecol. 2, 111-124.

Duke, S.O., Powles, S.B., 2008. Glyphosate: a once-in-a-century herbicide. Pest Manage. Sci. 64, 319-325.

Dunfield, K.E., Germida, J.J., 2001. Diversity of bacterial communities in the rhizosphere and root interior of field-grown genetically modified Brassica napus. FEMS Microbiol. Ecol. 38, 1-9.

Dunfield, K.E., Germida, J.J., 2003. Seasonal changes in the rhizosphere microbial communities associated with field-grown genetically modified canola (Brassica napus). Appl. Environ. Microbiol. 69, 7310-7318.

Dunfield, K.E., Germida, J.J., 2004. Impact of genetically modified crops on soil- and plant-associated microbial communities. J. Environ. Qual. 33, 806-815.

Durkin, P., 2003. Glyphosate-human health and ecological risk assessment. Final Report. USDA, Forest Service, 62 pp.

Feije, F., Anger, V., 1972. Spot test in inorganic analysis. Anal. Chim. Acta 149, 363-367.

Fehr, W., Caviness, C., Burmood, D.T., Pennington, J.S., 1971. Stage of development descriptions for soybeans, Glycine max (L.) Merrill. Crop Sci. 11, 929-931.

Forlani, G., Mangiagalli, A., Nielsen, E., Suardi, C.M., 1999. Degradation of the phosphonate herbicide glyphosate in soil: evidence for a possible involvement of unculturable microorganisms. Soil Biol. Biochem. 31, 991-997.

Franchini, J.C., Crispino, C.C., Souza, R.A., Torres, E., Hungria, M., 2007. Microbiological parameters as indicators of soil quality under various soil management and crop rotation systems in southern Brazil. Soil Till. Res. 92, 18-29.

Giesy, J.P., Dobson, S., Solomon, K.R., 2000. Ecotoxicological risk assessment for Roundup ${ }^{\circledR}$ herbicide. Rev. Environ. Contam. Toxicol. 167, 35-120.

Gomez, E., Ferreras, L., Lovotti, L., Fernandez, E., 2009. Impact of glyphosate application on microbial biomass and metabolic activity in a Vertic Argiudoll from Argentina. Eur. J. Soil Biol. 45, 163-167.

Griffiths, B.S., Caul, S., Thompson, J., Birch, A.N.E., Cortet, J., Andersen, M.N., Krogh, P.H., 2007. Microbial and microfaunal community structure in cropping systems with genetically modified plants. Pedobiologia 51, 195-206.

Gyamfi, S., Pfeifer, U., Stierschneider, M., Sessitsch, A., 2002. Effects of transgenic glufosinate-tolerant oilseed rape (Brassica napus) and the associated herbicide application on eubacterial and Pseudomonas communities in the rhizosphere. FEMS Microbiol. Ecol. 41, 181-190.

Haney, R.L., Senseman, S.A., Hons, E.M., Zuberer, D.A., 2000. Effect of glyphosate on soil microbial activity and biomass. Weed Sci. 48, 89-93.

Haney, R.L., Senseman, S.A., Krutz, L.J., Hons, F.M., 2002. Soil carbon and nitrogen mineralization as affected by atrazine and glyphosate. Biol. Fertil. Soils 35, 35-40.

Hart, M.M., Powell, J.R., Gulden, R.H., Dunfield, K.E., Pauls, K.P., Swanton, C.J., Krilonomos, J.N., Antunes, P.M., Koch, A.M., Trevors, J.T., 2009. Separating the effect of crop from herbicide on soil microbial communities in glyphosateresistant corn. Pedobiologia 52, 253-262.

Hungria, M., Franchini, J.C., Brandão-Junior, O., Kaschuk, G., Souza, R.A., 2009 Soil microbial activity and crop sustainability in a long-term experiment with three soil-tillage and two crop-rotation systems. Appl. Soil Ecol. 42 288-296.

Hungria, M., Mendes, I.C., Nakatani, A.S., Reis-Junior, F.B., Morais, J.Z., de Oliveira, M.C.N., Fernandes, M.F., 2014. Effects of the glyphosate-resistance gene, herbicides on soybean: Field trials monitoring biological nitrogen fixation, yield. Field Crops Res. 158, 43-54.

ISAAA (International Service of the Acquisition of Agri-Biotech Applications), 2012 Available at: http://www.isaaa.org/resources/publications (verified 21.09.12).

Johal, G.S., Huber, D.M., 2009. Glyphosate effects on diseases of plants. Eur. J. Agron. $31,144-152$

Jonge, H., Jonge, L.W., 1999. Influence of $\mathrm{pH}$ and solution composition on the sorption of glyphosate and prochloraz to a sandy loam soil. Chemosphere 39, 753-763.

Kaschuk, G., Alberton, O., Hungria, M., 2010. Three decades of soil microbial biomass studies in Brazilian ecosystems. Lessons learned about soil quality and indications for improving sustainability. Soil Biol. Biochem. 42, 1-13.

Kaschuk, G., Alberton, O., Hungria, M., 2011. Quantifying effects of different agricultural land uses on soil microbial biomass and activity in Brazilian biomes: inferences to improve soil quality. Plant Soil 338, 467-481.

Kremer, R.J., Means, N.E., Kim, S.J., 2005. Glyphosate affects soybean root exudation and rhizosphere microorganisms. Int. J. Environ. Anal. Chem. 85, 1165-1174.

Liphadzi, K.B., Al-Khatib, K., Bensch, C.N., Stahlman, P.H., Dille, J.A., Todd, T., Rice, C.W., Horak, M.J., Head, G., 2005. Soil microbial and nematode communities as affected by glyphosate and tillage practices in a glyphosate-resistant cropping system. Weed Sci. 53, 536-545.

Liu, W., Lu, H.H., Wu, W., Wei, Q.K., Chen, Y.X., Thies, J.E., 2008. Transgenic Bt rice does not affect enzyme activities and microbial composition in the rhizosphere during crop development. Soil Biol. Biochem. 40, 475-486.

Lopes, A.A.C., Souza, D.M.G., Chaer, G.M., Reis Junior, F.B., Goedert, W.J., Mendes, I.C. 2013. Interpretation of microbial soil indicators as a function of crop yield and organic carbon. Soil Sci. Soc. Am. J. 77, 461-472.

Lottmann, J., Heuer, H., Smalla, K., Berg, G., 1999. Influence of transgenic T4lysozyme-producing potato plants on potentially beneficial plant-associated bacteria. FEMS Microbiol. Ecol. 29, 365-377.

Lukow, T., Dunfield, P.F., Liesack, W., 2000. Use of the T-RFLP technique to assess spatial and temporal changes in the bacterial community structure within an agricultural soil planted with transgenic and non-transgenic potato plants. FEMS Microbiol. Ecol. 32, 241-247.

McCune, B., Mefford, M.J., 2011. PC-ORD. Multivariate Analysis of Ecological Data. Version 6.0. MjM Software, Gleneden Beach, OR

Mendes, I.C., Fernandes, M.F., Chaer, G.M., Reis Junior, F.B., 2012. Biological functioning of Brazilian Cerrado soils under different vegetation types. Plant Soi 359, 183-195.

Mielke, P.W., Berry, K.J., 2000. Permutation Methods: A Distance Function Approach. Springer-Verlag, NY, USA, pp. 352

Motavalli, P.P., Kremer, R.J., Fang, M., Means, N.E., 2004. Impact of genetically modified crops and their management on soil microbially mediated plant nutrient transformations. J. Environ. Qual. 33, 816-824.

Mulder, C., Wouterse, M., Raubuch, M., Roelofs, W., Rutgers, M., 2006. Can transgenic maize affect soil microbial communities? PLoS Comput. Biol. 2, 1165-1172.

Nogueira, M.A., Albino, U.B., Brandão-Junior, O., Braun, G., Cruz, M.F., Dias, B.A. Duarte, R.T.D., Gioppo, N.M.R., Menna, P., Orlandi, J.M., Raiman, M.P., Rampazo, L.G.L., Santos, M.A., Silva, M.E.Z., Vieira, F.P., Torezan, J.M.D., Hungria, M. Andrade, G., 2006. Promising indicators for assessment of agroecosystems alteration among natural, reforested and agricultural land use in southern Brazil. Agric. Ecosyst. Environ. 115, 237-247.

Pereira, J.L., Picanco, M.C., Silva, A.A., Santos, E.A., Tome, H.V.V., Olarte, J.B., 2008. Effects of glyphosate and endosulfan on soil microoragnisms in soybean crop. Planta Daninha 26, 825-830.

Puglisi, E., Del Re, A.A.M., Rao, M.A., Gianfreda, L., 2006. Development and validation of numerical indexes integrating enzyme activities of soils. Soil Biol. Biochem. 38, 1673-1681.

Reddy, K.N., Hoagland, R.E., Zablotowicz, R.M., 2001. Effect of glyphosate on growth, chlorophyll, and nodulation of glyphosate on growth, chlorophyll, and nodulation in glyphosate-resistant and susceptible soybean (Glycine max) varieties. J. New Seeds 2, 37-52.

SAS Institute, 1999. Proprietary of Software, Version 8, 6th ed. SAS Institute, Cary NC.

Silva, A.P., Babujia, L.C., Franchini, J.C., Souza, R.A., Hungria, M., 2010. Microbia biomass under various soil- and crop-management systems in short- and longterm experiments in Brazil. Field Crops Res. 119, 20-26.

Sokal, R.R., 1979. Testing statistical significance of geographic-variation patterns Syst. Zool. 28, 227-232.

Souza, R.A., Babujia, L.C., Silva, A.P., Guimarães, M.F., Arias, C.A., Hungria, M., 2013. Impact of the ahas transgene and of herbicides associated with the soybean crop on soil microbial community. Transgenic Res. 22, 877-892.

Souza, R.A., Hungria, M., Franchini, J.C., Chueire, L.M.O., Barcellos, F.G., Campo, R.J., 2008a. Quantitative and qualitative evaluations of soil microbes and biologica nitrogen fixation in soybean. Pesq. Agropec. Bras. 43, 71-82.

Souza, R.A., Hungria, M., Franchini, J.C., Maciel, C.D., Campo, R.J., Zaia, D., 2008b. Minimal set of parameters for evaluation soil microbiota and biological nitrogen fixation in soybean. Pesq. Agropec. Bras. 43, 83-91. 
Stott, D.E., Andrews, S.S., Liebig, M.A., Wienhold, B.J., Karlen, D.L., 2010. Evaluation of $\beta$-glucosidase activity as a soil quality indicator for the soil management assessment framework. Soil Sci. Soc. Am. J. 74, 107-119.

Sylvia, D.M., Fuhrmann, J.J., Hartel, P.G., Zuberer, D.A., 2005. Principles and Applications of Soil Microbiology, 2nd ed. Prentice Hall, New Jersey, pp. 645.

Tabatabai, M.A., 1996. Soil enzymes. In: Weaver, R.W., Angle, S., Bottomly, P.J. Bezdicek, D., Smith, S., Tabatabai, M.A., Wollum, A. (Eds.), Methods of Soil Analysis. Part 2. Microbiological and Biochemical Properties. Soil Science Society of America, Inc., Madison, pp. 775-833.

Van Eerd, L.L., Hoagland, R.E., Zablotowicz, R.M., Hall, J.C., 2003. Pesticide metabolism in plants and microorganisms. Weed Sci. 51, 472-495.

Vance, E.D., Brookes, P.C., Jenkinson, D.S., 1987. An extraction method for measuring soil microbial biomass C. Soil Biol. Biochem. 19, 703-707.

Wallis, P.D., Haynes, R.J., Hunter, C.H., Morris, C.D., 2010. Effect of land use and management on soil bacterial biodiversity as measured by PCR-DGGE. Appl. Soil Ecol. 46, 147-150.

Ware, G.W., 2000. The Pesticide Book. Thomson Publications, Fresno, 193 pp.

Weaver, M.A., Krutz, L.J., Zablotowicz, R.M., Reddy, K.N., 2007. Effects of glyphosate on soil microbial communities and its mineralization in a Mississippi soil. Pest Manage. Sci. 63, 388-393.

Weber, J.B., Best, J.A., Gonese, J.U., 1993. Bioavailability and bioactivity of sorbed organic chemicals. In: Linn, D.M. (Ed.), Sorption and Degradation of Pesticides and Organic Chemicals in Soil. American Society of Agronomy and Soil Science Society of America, Madison, WI, pp. 153-196.

Wei, X.D., Zou, H.L., Chu, L.M., Liao, B., Ye, C.M., Lan, C.Y., 2006. Field released transgenic papaya affects microbial communities and enzyme activities in soil. Plant Soil 285, 347-358.
Weinert, N., Meincke, R., Schloter, M., Berg, G., Smalla, K., 2010. Effects of genetically modified plants on soil microorganisms. In: Mitchell, R., Gu, J.-D. (Eds.), Environmental Microbiology. , 2nd ed. John Wiley \& Sons, Inc., Hoboken, pp. 235-258.

Wiren-Lehr, S., Komoba, D., Glabgen, W.E., 1997. Mineralization of $\left[{ }^{14} \mathrm{C}\right]$ glyphosate and its plant-associated residues in arable soils originating from different farming systems. Pestic. Sci. 51, 436-442.

Zhang, X., Ma, L., Gilliam, F.S., Wang, Q., Li, C., 2012. Effects of raised-bed planting for enhanced summer maize yield on rhizosphere soil microbial functional groups and enzyme activity in Henan Province, China. Field Crops Res. 130, $28-37$.

Zilli, J.E., Botelho, G.R., Neves, M.C.P., Rumjanek, N.G., 2008. Efeito de glyphosate e imazaquin na comunidade bacteriana do rizoplano de soja (Glycine max (L.) Merrill) e em características microbiológicas do solo. Rev. Bras. Cienc. Solo 32, 633-642.

Zobiole, L.H.S., Kremer, R.J., Oliveira Jr., R.S., Constantin, J., 2010a. Glyphosate affects micro-organisms in rhizospheres of glyphosate-resistant soybeans. J. Appl. Microbiol. 110, 118-127.

Zobiole, L.H.S., Kremer, R.J., Oliveira Jr., R.S., Constantin, J., 2010b. Glyphosate affects photosynthesis in first and second generation of glyphosate-resistant soybeans. Plant Soil 336, 251-265.

Zobiole, L.H.S., Oliveira Jr., R.S., Huber, D.M., Constantin, J., Castro, C., Oliveira, F.A., Oliveira Jr., A., 2010c. Glyphosate reduces shoot concentration of mineral nutrients in glyphosate-resistant soybeans. Plant Soil 328 , 57-69. 